\title{
Poetics Contra Psychoanalysis
}

\begin{abstract}
This essay argues that psychoanalytic literary criticism has largely failed because it has assumed that literature and psychoanalysis share common analytical ground. I contend that psychoanalytic approaches necessarily deform literature, that literary readings deform psychoanalytic theory, and that the assumption of commonality between poetics and psychoanalysis causes psychoanalytic literary criticism to go astray. I advocate the opposite approach: setting poetics against psychoanalysis, contending that where their mutual tension and disfigurement is recognized and investigated, psychoanalysis and literature can become genuinely available to one another.
\end{abstract}

Keywords psychoanalytic criticism, psychoanalysis, hermeneutics, interpretation

Acknowledgements: I am grateful to Danny Smith, and to Tom Jones and members of the English Research Seminar at the University of St. Andrews for their comments on previous versions of this paper. 
Modern and "post-modern” critics must have felt relieved that Jacques Lacan's theory spared them the pain of having to experience what analysis truly is, if one would use it for literary purposes.

—André Green, “The Function of Writing”

[T] he analytical literary critic ... does not like to see the text as something that ends up greater than the individual who wrote it[.]

—Valerie Sinason, "Literary criticism and psychoanalysis: partners or millstones?"

\section{Literature and Psychoanalysis}

"Psychoanalytic literary criticism," Peter Brooks wrote in 1987, "has always been something of an embarrassment" (1987: 334). It remains unclear how criticism might at once be psychoanalytic and literary, without compromising either half of the equation. The literary exemplar employed in psychoanalytic theory (Sophocles for Freud, Poe for Lacan) might superficially resemble literary criticism, but its function is to illustrate and complicate analytic theory. Nietzsche's Birth of Tragedy was not well received by philologists, but philosophers judge it by other criteria. Likewise, whether or not Freud's interpretation of Oedipus Rex holds water for classicists, or Hamlet for Shakespeareans, is, for psychoanalysis, beside the point. Psychoanalytic approaches to literary criticism, however, have always been at risk of falling back into exemplar, by using literary texts to advance or demonstrate psychoanalytic postulates at the cost of what is particular to the text in question. An approach which affirms "the anteriority and superiority of psychoanalysis facing literature," Jean-Michel Rabaté writes, "does not entail, in fact, that the results will be false or the method wrong, but simply—and more damagingly perhaps — that they 
are entirely predictable" (2012: 54). ${ }^{1}$ Where "applied psychoanalysis" downplays the difference between analysis and literary criticism, the casualties are always literary.

It may seem that literary critics ought to rein in psychoanalysis so that the two might get along more equitably. But a commensurate risk is posed by confining psychoanalysis to strictly textual matters. For critics, disposed to questions of writing and writers, it has been "all too easy to prove Freud merely literary, to mirror our avoidance of scientific, humanistic, therapeutic responsibility"; in short, to treat Freud as "just another writer" (Gallop 1979: 51; Patterson 2002: 130). Of course, we can point out literature's own responsibilities and entanglements, but one thing is intractable: to subsume psychoanalytic theory under writing, and its practice under textual criticism, is to give something up; "the choice to read as literary text is always a bracketing of something practical which cannot be forgotten" (Gallop 1979: 51). While it is reductive to explain a particular literary text by appealing to a general psychoanalytic principle, it is similarly reductive to cast psychoanalytic theory as a project of writing.

By conceiving of psychoanalytic theory as writing, literary critics have been able to see psychoanalytic practice as "one more hypothesis of reading, unanchored from any reality." (Brooks 2000: 3) If psychoanalysis is supposed to be essentially about "reading" people, dreamtexts and case histories, its procedures appear readily available to literary criticism. The appeal of the perceived likeness between the two is what Jane Gallop memorably called "the seduction of an analogy." But enamored misreadings of psychoanalysis as a method of textual criticism (an "approach" or "perspective," in the idiom of literary theory primers) open the way for a vague and generalizing redeployment of psychoanalytic concepts. Repression can end up meaning both a mind's unconscious capacity to hide unassimilable material and intentional actions taken to silence political opposition, allowing a critic to speak of repression in ways antithetical to psychoanalysis. Trauma risks becoming a catch-all term to explain, for readers who see everything as representations, anything which is not represented. What has resulted from this

\footnotetext{
${ }^{1}$ On this point cf. Felman 1977a: 5-10; Groeben 1984; Bersani 1986: 45ff.
} 
conceptual dilution is a "Freudian hermeneutic" that is hollowed out and "divested, to be sure, of its own specific content" (Jameson 1971: 15). Psychoanalytic literary interpretation is transformed into a purely critical stance, without the psychological realism-not to mention positivism-essential to psychoanalysis proper. In the worst cases, we encounter a re-heated de Manian dish in which psyches are like texts solely because both prove "unreadable." Here is the impasse: make literature the demonstration of psychoanalysis and you will regret it; make psychoanalysis a mode of criticism and you will regret it. Either conquest impoverishes the territory that it annexes. We have cause to ask what else might lie in "the 'between' of therapy and hermeneutics" (Jacobus 1998: 101).

In this essay I address the problem by considering the possible relations of poetics to psychoanalysis. The question of how the two relate has remained unresolved since the mid1980s, when Michel Grimaud observed that "the potential for psychopoetics is great, but there are few convincing results" (1984: 341). Intuitively, this claim for potential seems correct: theorists and readers of poetry, for instance, require the sort of very close attention to language, and to questions of form and performance, that psychoanalysts might employ in analysis. Poetics and psychoanalysis seem to share enough ground for cooperation to be possible, sympathetic critics have long suggested; "we sense that there ought to be, that there must be, some correspondence between literary and psychic process, that aesthetic structure and form, including literary tropes, must somehow coincide with the psychic structures and operations they both evoke and appeal to" (Brooks 1987: 337). But the anticipated convergence has not emerged.

There have been several productive results from the encounter of psychoanalysis and poetics since the 1980s, of course, but these cases have involved one side borrowing, or being lent, the other's expertise. The field of rhetoric has responded with some enthusiasm to Lacanian theory (Gunn 2004a, 2004b, Lundberg 2004). There has also been a substantial engagement with the literary aspects of psychoanalytic theory, its structures and aesthetics, and the central role of 
metaphor in analytic practice (Jacobus 2005; Szajnberg 1997; Ingram 1996; Enckell 1999; Civitarese and Ferro 2013). But cases in which literary concepts are "applied" to the material of psychoanalysis or vice versa (as one "applies" a hammer to a nail), do not constitute the exception but the rule. Since Shoshana Felman's call for a (Lacanian) "new way of reading," the contributions of Lacanians to literary questions have been considerable, and they deserve special attention in this brief review (1977a: 118). Bowie warns that while it is convenient to see Lacan providing literary studies with the tools to "think incisively about literary works as productions of desire," the relationship between Lacan and literature is ultimately "an asymmetrical one" (1987: 155). Lacan may read Saussure and quote Joyce, but he is no literary critic. I will return to this asymmetry in section three.

Following the pivotal work of Shoshana Felman and Barbara Johnson, and the translation of French theorists such as Jacques-Alain Miller and Jean-Claude Milner, the Lacanian who has aroused the most interest across the Anglophone theoretical humanities has been, of course, Slavoj Žižek, whose brand of syncretic critical theory exemplifies the paradoxical psychoanalytic engagement with cultural and textual criticism. On the one hand, Žižek is obsessed with form. He maps the figure of the triad from Hegel's Universal-Particular-Singular to Lacan's Imaginary-Symbolic-Real, to the Christian Trinity, to the trio of Abrahamic religions, and so on. He is forever proposing formal maps and explanations, from the transcription of Otto Weininger's Sex and Character into a semiotic square to creative redeployments of Lacan's four discourses (Žižek 1994: 137-166; Žižek 1998: 74-113). He therefore seems ideally placed to locate the commonalities between psychoanalytic formalism and literary poetics. Yet in practice "there seems to be no cultural phenomenon that ... Žižek cannot master" because for him the Lacanian scheme occupies a higher order to particular artistic forms (Dean 2002: 23). Ultimately, "everything can turn into an example, an illustration. There is no a priori difference in status between literary texts, films, television programmes, cartoons, newspaper articles, stories we have just heard, dreams, jokes, you name it" (Rabaté 2001: 8-9). The considerable enjoyment found in 
reading Žižek's “applied” psychoanalytic work doesn't come from his interpretation of Hitchcock or Spinoza or neoliberalism per se but from the recognition that a familiar HegelianLacanian rabbit has been pulled from another unexpected hat. The most popular psychoanalytic theorist of recent years has succeeded as a critic through his ability to develop exemplars from everything. But for this reason, Žižek's work, and that which follows in his train, does not make a claim on the literary. Once more, "literature and psychoanalysis" turns out to mean "literature or psychoanalysis."

This essay contends that psychoanalytic literary criticism has largely failed because it has assumed that literature and psychoanalysis share common ground. Of course, there are more sophisticated ways to articulate this alleged commonality than by saying that psyches resemble poems (they do not, without extreme generalizing). Here is one more sophisticated version: "the making and unmaking of meaning in the context of psychoanalytic practice is inevitably subject to many of the same conditions and difficulties that come into play when we read a text" (Jacobus 1998: 102). This is not unreasonable: at least some good analysts and good literary critics are good in similar ways: sensitivity to detail, exegetical vigor, imagination and so on. But it does not follow that analysts and critics have a shared enterprise, any more than a mutual interest in verse unites greetings card writers and Rabbis. Literary writing does not survive the reduction to fantasy or sublimation, and psychoanalysis does not survive the reduction to textual criticism. Psychoanalytic literary criticism will fail wherever it is understood as a Venn diagram of "poetics" and "psychoanalysis", whose overlapping segment contain everything about which they can agree. In reality, any meeting of literature and psychoanalysis always disfigures one or both, and the damage is inevitable. Yet it is in their mutual disfigurement, I will argue, that literature and psychoanalysis do finally become available to one another-but only where critics can relinquish the ideal of their shared truth, and grasp, rather than efface, the resistance between them. 


\section{Two disfigurations}

Wherever the subject of an author and psychoanalysis is raised, claims of their similarity are never far behind. ${ }^{2}$ Of course, all critics tend to see in literature whatever they know best, and this is not necessarily a problem. In the case of psychoanalysis, however, the effect is different; in this section I consider in greater detail how claims of likeness between literature and psychoanalysis deforms or misreads one or both.

Firstly, I will consider a recent example of how psychoanalysis distorts literary critical writing. There are plentiful instances in which psychoanalytic criticism devolves into exemplars. Here is something approaching a limiting case of the claim of likeness from the psychoanalytic side. Benjamin and Thomas Ogden seem particularly well equipped to perform what they term psychoanalytic literary reading. The former holds a Ph.D in literature, the latter is a professional analyst. Better still, they are attuned to questions of method. Their essay "What is Psychoanalytic Literary Criticism?" starts promisingly with the admission that it "makes no attempt to find or create a correspondence between literary form or content ... and psychological operation" (2013: 10). Yet a connection is still ultimately proposed on the basis of likeness: their approach entails "a form of psychoanalytic literary thinking that is not psychologically explanatory, diagnostic, or therapeutic ... [but] derives from its particular way of hearing and writing about literary voice." (ibid. 10-11) Psychoanalysts ought to be good listeners, and so literature might be understood not through analytic theory but analytic practice, Ogden and Ogden contend. But plenty of good listeners are not psychoanalysts; the problem occurs when one attempts to say precisely what the two practices share.

\footnotetext{
2 See, for instance, claims for Shakespeare's likeness, verging on equivalence, to Freud surveyed in Hillman (2012: 99-103); the likeness of romanticism and psychoanalysis in Faflak 2007; various claims of "shared interests" between Dickens and Freud in Schlicke (2011: 138-9).
} 
The method the authors call "psychoanalytic literary reading" is articulated through commentary on an existing piece of criticism (by Thomas Ogden, in fact). This allows for some evasion. At times, Ogden and Ogden purport to know the thoughts of their exemplary "Psychoanalytic Literary Reader"; they assert that he "believes that voice in literature conveys particular feeling states, and that these emotional states of mind can be heard and understood in the same way that feeling states can be heard and understood when they are spoken by a patient, or by any other person" (ibid. 15-17). We can assume that Ogden and Ogden endorse the general position that patients and poems have sufficiently similar voices that they are comparable. Indeed, they must do if critics and psychoanalysts are to lend one another insight; for my argument, this is the crucial premise. When they come to the more contentious claimthat this likeness is perceived by the reader-they retreat into an observer's stance: “[t]he language here strongly suggests that the PLR's experience of reading a poem is a personal one that is very similar to the way he approaches meeting a person" (ibid. 16, my emphasis). The authors consciously or unconsciously deny responsibility for this claim, I think, simply because it is not very likely: a reader who experiences reading poems and meeting people in a "very similar" way must be doing at least one rather strangely, or meet only very composed people. A poem's "voice" might resemble the "voice" of a letter from a real person, perhaps, but even this risks a false equivalence: a poem does not represent a person as a letter does; belief in such equivalence leads back to the overly literal psychoanalytic readings Ogden and Ogden are attempting to get beyond.

The use of the category of voice to link poems and patients demonstrates a deeper problem. As a crude index of its complexity as a concept for poetics, consider the difference of perspective between the entry for voice in The New Princeton Encyclopedia of Poetry and Poetics (1993) and its successor, The Princeton Encyclopedia of Poetry and Poetics, Fourth Edition (2012). The 1993 entry states that "within romantic theories of poetry" (meaning theories from the British romantic period), voice "plays a significant role as the embodiment of the author's expression," 
but that this view "has been qualified by much modern theory," to such a degree, in fact, that the majority of the entry is given over to structuralist, Marxist and poststructuralist repudiations of those earlier conceptions of poetic voice as "what a specific author 'wants' to say" (Gudas and Davidson: 1366-1367). The closing line of the 1993 entry notes the paradox that these repudiations have accompanied a continued interest in orality. The 2012 entry gives far more space to such interest. It also states the paradox more fully: "to define voice in written poetry immediately poses a problem, for there is no literal voice in the poem: voice is an oral metaphor," and yet "regardless of how much one insists that writing is not speaking and that voice is not literally present in the poem, literary critics have persistently relied on metaphors of voice to analyze writing ... metaphors of orality continue to inhabit, unsettle, and complicate the textual realm to the present day" (Richards 2012: 1525). For something that allegedly doesn't exist, the voice of the written poem is rather persistent. "Voice" is not sufficiently determined within poetics for it to be a stable link to something without. ${ }^{3}$ But more significantly for us, the complexities internal to poetics are precisely what we lose when thinking about "voice" in psychoanalytic ways, because these complexities are created by the tension between a written text and the oral performances it can both demand and elude. A similar tension emerges when the authors attribute the "feelings and ideas" in a poem to "fictional characters," yet define those characters as "imaginary beings whose origins in the author's mind is undeniable" (Ogden and Ogden 2013: 17). The first move frees their reading from biographical criticism while running the risk of turning all psychologically rich poems into dramatic monologues, but the second move buys psychological realism back from that same author who had just been asked to leave. ${ }^{4}$

Ogden and Ogden's psychoanalytic literary reader is able "to treat narrative voice as if it were the voice of a real person without ever leading the reader to feel that he has lost his awareness that the voice is not that of a real person." (2013: 18) This "as if" is the seductive

\footnotetext{
${ }^{3}$ On indeterminacy see Nowell Smith 2015: 1-14.

4 On the opposition between the assumptions of dramatic monologue and a broader sense of lyric "voice" see Culler 2015 chapter 6.
} 
analogy in action. Indeed, the essay demonstrates with admirable clarity the paradox that "psychoanalytic literary reading" requires: read as if you are an analyst attending a patient, but never commit the mistake of believing this is what you are doing-because the belief implied by the practice is not sustainable. There are ways to handle voice that do not imply an empirical speaker, of course: one might speak of a poem's voice as the sum of its aural and tonal qualities, or speak of the ways in which that voice resists any empirical, actual performance. There is the phone/gramma couple in Derrida's work. But the central issue here is that the category of voice cannot simultaneously sustain poetics and psychoanalysis; it cannot encompass both the tension between orality and textuality and admit the psychology of a real (or "as if" real) person, because to do either would be explicitly to undermine the other. While aiming to study the poem itself, psychoanalytic readers must find a way to refer back to an empirical or imagined person, yet this will always conflict with the imperative to study what is written:

He [the critic] is not so naïve as to believe that a literary work is the thinking and feeling state of the writer transposed into verbal form. Rather, [the critic] treats the literary work as a creation, in the medium of writing, of a state of mind that the author has experienced in the past or is experiencing (perhaps for the first time) in the very act of writing. (ibid. 16)

The authors are clearly aware of the pitfalls of "naïve" psychoanalytic criticism. Yet in order to open up the poem to psychoanalytic attention, they proceed "as if" analyzing a real person, and then smuggle one (namely Robert Frost) back into the poem through "the very act of writing." To claim that experience of writing is captured in the work is necessarily to set voice to one side, and to read a poem "as if it were the voice of a real person" is to bypass all the compositional work that real people don't do when they speak; one cannot have it both ways. What a psychologically realistic concept of voice cannot encompass, almost by definition, is "the 
medium of writing." Thus the category of voice is like a paperclip in a fuse-box; it makes the connection, but it doesn't really fit. Sooner or later poem is deformed into a patient-it represents "a state of mind" to the point of allegedly providing access to it. ${ }^{5}$

This essay is revealing because it is unusually sophisticated and self-conscious-it goes beyond the assumption that psychoanalysis demystifies literature because psychoanalysis demystifies all human activity — and yet remains caught on the snag of likeness. The problem is not so much that Ogden and Ogden fail to find much of interest to other readers of Frost, but that by approaching poetry as "the voice of a real person" they foreclose everything that makes Frost's poetry more interesting to literary criticism than Frost's breakfast-table conversation. Wherever attention is paid to poetics, we cannot honestly sustain the belief that the poem's "voice" is of the same kind as a person's. Even if the analysis of metrical stress, say, reveals something about poems and people, this hardly means that a trochaic sonnet is interesting in the same way as a trochaic patient. Regardless of the care taken, this approach, insofar as it is psychoanalytic, it fails to find purchase on the literary. Where overlap appears possible, it is only because the poem has been more or less willfully read as something it is not. More generally, we cannot expect psychoanalysis and poetics to meet by going back to "applied psychoanalysis" and attempting to improve its eye for poetic form, or its ear for verse rhythm, because it is in the very "application" that poetry is mistaken for, or treated as, analytic speech, and poetry's formal qualities are necessarily overlooked because poems are unlike patients, and the extent to which a poem resembles other poems more than analytic sessions, lectures or recipes is poetics.

\footnotetext{
5 This sense that poems provide access to real people is necessary to justify psychologically realistic reading, but thanks to the effort to avoid reductive psychobiography, that access can become very hazy. In the earlier essay, we are told that a line of Frost's "conveys a sense of the poet's attempts, in his making of poems, to create and preserve ... the voices of the people he has loved, the voices of the poems that have mattered most to him, the changing sounds of his own voice in the course of his life (both in speech and in the poems that he has written), as well as the sounds of ancestral voices..." Rather than capturing anything specific (and therefore lapsing into biographical criticism) this approach attempts to affirm the "personhood" of a line of verse by detecting every conceivable echo of any poet's psychic history (Ogden 1998: 433-4).
} 
Although it is less common, disfiguring does occur in the opposite direction. Some criticism, as I have noted, adapts psychoanalytic concepts wholesale into literary-critical tropes. Where psychoanalysis is borrowed by "suspicious" hermeneutics, no explicit dependence on psychoanalysis endures. Such work I will bracket here, since it is not concerned with establishing a relation between psychoanalysis and criticism. ${ }^{6}$ The more interesting case for this discussion is where psychoanalysis is not dissolved into criticism, and yet is said to be like literary reading in some way. Robert Young and, more recently Lesley Chamberlain, have approached Freudian theory through the lens of the novel (Young 1999: 206-231; Chamberlain, 2000). This is one way of making a literary claim on psychoanalysis, and Freud's writing can certainly sustain literary analysis (of course, for good critics, almost anything can). A more complex and provocative example is the role of the categories of literature and storytelling in the work of a practicing analyst, Adam Phillips. In his books, Phillips often flirts with the suggestion that psychoanalysis may, in fact, be a category of literature:

"Freud experienced the subject matter [of case histories] as a form of temptation: call it the temptation of the literary"

"If psychoanalysis was not an applied science, perhaps it was an applied literature"

"Why have analysis when you can read?” (2003: 11, 116-17; 2000: 375)

As well as flattering his readers with the suggestion that they, not his clinical patients, might be receiving the privileged form of treatment, Phillips is willfully provoking analysts and theorists at moments such as these. Commenting on his recent biography of Freud, John Forrester observed that 'Phillips' Freud becomes Freud by discarding theory: his is a 'psychological' and writerly

\footnotetext{
${ }^{6}$ On the relation of psychoanalysis to "suspicious" critique see Felski, 2011: 215-234.
} 
Freud" at the cost of being a therapist, a doctor and a scientific researcher (2015: 114-115). But it is not the case that Phillips wrestles Freud away from science only to suit his own taste. Rather, Phillips enacts the ambivalence that, on his account, psychoanalysis feels towards literature. $\mathrm{He}$ suggests that psychoanalysis is a kind of storytelling:

"[P]sychoanalysts ... are only telling stories about stories" (1997: xvi).

"Freud was to make a story about adult life out of a story about childhood; a story about development out of a story about assimilation. A story about civilization out of a story about immigration. And, ultimately, a story about the individual's elemental desire for extinction" (2014: 43).

At the same time, Phillips argues that the literary is precisely what psychoanalysis cannot tolerate: "the 'creative artist' seems to be used as a kind of limit factor for the reach of psychoanalysis; someone the analyst can define herself against"; and moreover, "[t]he idealization of art and artists among psychoanalysts who write is always accompanied by its shadow of envy" (Phillips 2000: 80; Phillips 1995: 81). For Phillips, the artist represents a limit because psychoanalysts cannot, at the cost of their professional identity, admit to being "creative writers," even if they might aspire to a poet's facility with language. Of course, to prohibit psychoanalysis from being a kind of poetry may only intensify the wish. The existence of poetry legitimates the very close attention that analysts attempt to pay to language, while at the same time threatening the notion that analysts have a privileged understanding of it. Poets have mostly managed to write without psychotherapy, and "psychoanalysts might sometimes need poetry, in ways that poetry might not need psychoanalysis" (Phillips 2000: 30).

Phillips' Freud may be a corrective to the tendency to reify psychoanalysis as a straightforward therapeutic procedure or a positivist theory of mind, if we still need one. But his 
elegant accounts stray towards a commensurate category mistake insofar as they commit psychoanalysis to a branch of literary writing (indeed, Phillips' stylistic prowess may be partly responsible). If sexuality is constituted by our failure to tell sufficiently satisfying stories about what we desire, as Phillips might say, it hardly follows that novelists know their own desires better than other people. If psychoanalysts do tell stories about what life is like, they ask very different things of narrative; crucially, they do not expect a sufficiently good story of the sexual to render it transparent-due to the way psychoanalysis conceives of the problem, no description ever could. The unconscious is not primarily a problem of description. And while it is indebted to literature in obvious ways, psychoanalysis depends for its existence on generalizing beyond literature, just as it borrows from history, anthropology and religion while generalizing beyond them. The category of "stories" works similarly for Phillips to "voice" for Ogden and Ogden: it seems to unite both literary and psychoanalytic writing, while blurring the incompatibility; the point at which psychoanalysts "are only telling stories" is the point at which all of the aspirations to scientific research, to therapeutic authority and even to truth claims must fall away.

Literary readings disfigure psychoanalysis for the same reasons that psychoanalytic readings disfigure poems: neither is a special or general form of the other. Psychoanalysis is bound to be frustrated if it tries to ground its theories on the slopes of Helicon. "The psychoanalytic paradigm visible in the literary text must by definition be visible elsewhere too" (Bowie 1987: 15). Its commitments always eclipse the literary, and thus it gives up its access to the particularities of literature, its access to poetics. Julia Kristeva, one of the best readers of literature amongst contemporary psychoanalysts, nevertheless in her analysis of "poetic language" aims at "a practice for which any particular language is at the margin" (1980: 24). Psychoanalysis might depend on "poetry," as Phillips claims, but insofar as it remains a theory of the psyche, it cannot depend on any particular poems. 


\section{Against mastery}

When Freud addresses the topic of textual composition in "Creative Writers and DayDreaming," he displays some of the envy that Phillips attributes to psychoanalysis: his principal models for writers are the imaginative play of children and its continuation in adults as daydreaming. By aligning writing with daydreaming Freud makes a claim for the primacy of fantasy, but he also implies that "creative writing" differs only by degree from that easy and pleasurable pastime:

We are perfectly aware that very many imaginative writings are far removed from the model of the naïve daydream; and yet I cannot suppress the suspicion that even the most extreme deviations from that model could be linked with it through an uninterrupted series of transitional cases. (Freud 2001 [1908]: 150)

Fantasy implies choosing the pleasurable over the actual; in this essay the desire to master the literary trumps the reality of which Freud is "perfectly aware." He cannot relinquish the "suspicion" that writing is essentially a prosthesis for the psyche: that it is, in the final analysis, always the fictional fulfilment of real wishes. The reward for Freud in giving way to that "suspicion" is that insofar as psychoanalysis understands people and their wishes, it already understands literature. This bargain recurs essentially unchanged in a remark of André Green's:

[T] he text implies for the writer the desire to write, and the desire to be read, and for the reader the desire to read, a remote substitute for the desire to see and to know which is an integral part of all sexual curiosity. (Green 1997 [1986]: 339) 
Green extends psychoanalytic attention to what, after Roland Barthes, we can call readerly desire, but the logic is the same; the literary (as a technical discipline, i.e. poetics) becomes a series of hermeneutic obstacles or obfuscations behind which something more general ("sexual curiosity") still operates. I have suggested that where the literary is understood as a consequence or symptom of the psychological, poetics becomes impossible. In $S / Z$, Barthes writes: "the very being of writing (the meaning of the labor that constitutes it) is to keep the question Who is speaking? from ever being answered" (1990 [1970]: 140). To offer an empirical, psychological answer is always to offer a non-literary "explanation" of the text whose logic stands outside of it.

This stance towards the literary persists across twentieth-century psychoanalysis, which makes Lacan's deviation from it all the more significant. It is an irony of the history of criticism that Lacan's work has been strongly associated with the adoption of psychoanalysis as a species of literary theory in English departments (hence André Green's comment in my epigraph) while Lacan himself was unusually forceful in his opposition to psychoanalytic literary criticism. It is perhaps because Lacan is one of the most gifted in the "syncretic" style; his borrowings are legion, and span a huge number of "theoretical" fields: Marxism, existentialism, structural linguistics and anthropology, cybernetics, ethics, visual art and so on, as well as literature. But for all Lacan's engagement with literature (Sophocles, Shakespeare, Poe, Joyce), he refuses to conflate psychoanalysis and literary criticism.

In a late paper, "Lituraterre," given in May 1971, and subsequently published in the journal Littérature, Lacan opposes the notion that psychoanalysis explains literature: "being appended to Oedipus by no means qualifies it [psychoanalysis] to find its way around in Sophocles' text. Freud's evocation of a text by Dostoyevsky does not suffice to say that textual criticism, until now the private hunting ground of the university discourse, has received any more clout from psychoanalysis," he asserts (2013 [1971]: 328). In the case of Sophocles, psychoanalysis's own commitments to Oedipus-'l'CEdipe du mythe'-do not grant it the key to 
Sophocles' Oedipus Rex; 'C'est pas pareil,' Lacan asserts (2009 [1971]: 2). ' We might also note that the literal meaning of Lacan's observation is that in Sophocles' text, psychoanalysis cannot find itself [s'y retrouver]. Moreover, to say that textual criticism has been the reserve of university discourse may be descriptively true, but by calling it a "private hunting ground" [chasse gardée], Lacan also suggests that when psychoanalysis engages with the literary, it is not contributing to professional literary criticism so much as poaching from the literary landscape for its own ends. Without necessarily condemning such poaching, Lacan repudiates the efforts of analysts to impose themselves on literature: "far from compromising myself in this literary love fest ... I denounce therein the attempt" (2013: 328).

Lacan unclasps psychoanalytic theory from literary criticism by weakening the former's claim on the latter. Commenting on his own famous essay on "The Purloined Letter," Lacan insists that it does not constitute literary criticism:

My critique, were it possible to take it as literary, could bear, and I do give it a go, only on what Poe does in being a writer who forms such a message about the letter. It is clear that in not saying it as such therein, it is not insufficiently, but all the more rigorously that he confesses it.

Nonetheless, the elision could not be elucidated by means of some feature of his psychobiography: if anything, the elision would rather be occluded by it.

(And so the psychoanalyst who has scoured Poe's other texts throws in her towel here.) (2013: 328-29).

Lacan's "critique" arrives at Poe's door because Poe's story contains-in its purloined, circulating, unrevealed letter—a message Lacan takes to be more generally significant; the drama of The Purloined Letter provides Lacan with a particularly good exemplar for his own tale because

\footnotetext{
${ }^{7}$ Some of Lacan's passing remarks in the lecture are not preserved in the printed version in Litterature, despite being rather pertinent, and here I rely on the transcription of Patrick Valas.
} 
Poe's sleight of hand is exemplary, but this is as "literary" as the criticism gets. The analyst "who has scoured," in Lacan's oblique reference, is Marie Bonaparte, his rival and the author of a twovolume study of Poe (Nobus 2013: 341). In claiming that such biographical work would obstruct Poe's "message about the letter," Lacan shows a "staunch refusal to reduce the meaning of any text to a psychobiographical 'housecleaning"' (Rabaté 2001: 33). His comment also repeats a central gesture Barbara Johnson observes running through Poe's tale, Lacan's “critique," and Derrida's subsequent commentary: "[t]he subversion of any possibility of a position of analytical mastery" (1977: 458).

Why does Lacan refuse psychoanalysis the position of mastery over literature? Recall this claim from the paper colloquially known as the "Rome Discourse": "Speech is in fact a gift of language, and language is not immaterial. It is a subtle body, but body it is. Words are caught up in all the body images that captivate the subject" (Lacan 2006 [1966]: 248). We might assume this to be the familiar assertion that language is embodied, or that bodies are linguistic, but there are two bodies in play here, the "subtle body" of language and the subject in whose body words get caught. Or to state the opposition in Leo Bersani's terms, there is "the untheorizable psyche, and ... the language that belongs to none of us but that we use as our principal means of selfunderstanding" (Bersani 2010: 416). Between the two lies what Lacan would elsewhere call the "problem" of "man's relationship to the letter" (Lacan 2006: 623). Were the psyche and language fully equivalent—able to accommodate one another — the "problem" would collapse, and with it Lacan's conception of the psychoanalytic field. If Lacan appears at times to bring psychoanalysis closer to textual analysis-not least by famously tying Freud's "condensation" and "displacement" to structural linguistics (2006: 412-41)—he nevertheless strenuously resists collapsing psychoanalysis into a feature of language. Gallop contends that for Lacan "the object of psychoanalytic study reveals itself as 'style"' (1984: 304). This puts to immediate use the particularity of Lacan's writing. But insofar as this supports Gallop's suggestion that "Lacan might see psychoanalysis as a regional branch of literary studies," both would seem, from the 
perspective of psychoanalysis, one more attempt to domesticate it (ibid. 304). By contrast, to insist that psychoanalysis is not at home in literature-that its cherished texts remain distinct from it - is also to preserve the differences between psychoanalytic theory and practice and the broader cultural and intellectual environment, which means, in the case of its appropriation by literary theory, to preserve "the truth of psychoanalysis" from becoming "nothing other than deconstruction" (Egginton 2007: 11).

We might turn now to a positive claim about criticism made in "Lituraterre." "If literary criticism could effectively renew itself," Lacan writes, "it would be because psychoanalysis is there for the texts to measure themselves against it, the enigma being on its side" (2013: 329). Criticism might renew itself, rather than having psychoanalysis tell it what is "really" going on, when texts can be measured against psychoanalysis, when psychoanalysis comes on the scene not as the reader-supposed-to-know but as an enigmatic figure. We can think of the typical relation posed between literature and psychoanalysis as one of verticality: psychoanalysis reveals what is "beneath" or "behind" the text, it "uncovers" the hidden content that was in literature more than literature itself, and does so by seeing through or past the surface. This interpretive verticality is figured by Freud most obviously in the manifest/latent scheme in The Interpretation of Dreams, a scheme continuous with Jameson's sketch of criticism as "not so much an interpretation of content as ... a revealing of it, a laying bare, a restoration of the original message, the original experience, beneath the distortions of the censor" (Jameson 1971: 16). ${ }^{8}$ By contrast, the relation suggested by Lacan's remarks is horizontal: "psychoanalysis is there for the texts to measure themselves against." I have been advocating that we think of poetics against psychoanalysis (remembering that the term against encompasses opposition and support, as when you lean against a tree). We might also understand this conjunction as poetics beside psychoanalysis, with all the tension Eve Sedgwick detects in that preposition: "Beside ... does not

\footnotetext{
${ }^{8}$ Interpretation in The Interpretation of Dreams is, at least by the 1911 edition, overwhelmingly vertical, although not exclusively so. I discuss this at some length in a forthcoming essay, "The Other Freudian Reading: Association and Aesthetics in The Interpretation of Dreams."
} 
depend on a fantasy of metonymically egalitarian or even pacific relations, as any child knows who's shared a bed with siblings. Beside comprises a wide range of desiring, identifying, representing, repelling, paralleling, differentiating, rivalling, leaning, twisting, mimicking, withdrawing, attracting, aggressing, warping, and other relations" (2003: 8). Once we dispense with the binary question of compatibility (where Oedipus or Hamlet either is, or is not, explained by his unconscious motivations, for instance), a whole spectrum of dynamic and non-reciprocal relations between psychoanalysis and literature become available to criticism.

I have suggested that by thinking of poetics against psychoanalysis we are better able to characterize the logic of existing psychoanalytic criticism. When Lacan repudiates the attempts of psychoanalysts to analyze literature, he dismisses them as "this literary love fest" [ce frotti-frotta littéraire], implying not only desire, but also physical contact and friction. But rather than write it off, this might offer a way to think more productively about psychoanalytic criticism's tendency to disfigure its objects. When psychoanalysis approaches the literary it always desires from the techniques and constraints of writing actual psyches and bodies, things we might want but can't get from writing. ${ }^{9}$ This desire, I have suggested, also emerges as its will to master literature, its will to engage with the literary on terms that are, in the final analysis, strictly psychoanalytic-to discover what it already knows. Yet if the disfigurement or deviation occurs by necessity, we can see the resulting friction as constitutive of the way psychoanalysis addresses art: by rubbing up against it. The friction between the psychoanalytic and the textual signals their disfiguration, but also demonstrates their "horizontal" contact.

It becomes possible to understand the whole history of psychoanalytic criticism as the history of its disfiguring force toward art, stretching from Freud's avian interpretation of Leonardo's The Virgin and Child with St. Anne to Žižek's allegorical transformation and "violation” of Hitchcock, and beyond (Cohen 1995: 350). Psychoanalysis has always been operating under

\footnotetext{
${ }^{9}$ Recall Jane Gallop's response to the absence of the body in Leo Bersani's The Freudian Body: Psychoanalysis and Art, an absence marked even by the tension between its title and subtitle: "'Bait and switch,' I thought bitterly. 'You fucking tease!"' (2010: 393)
} 
the assumption of psychology as first philosophy, the assumption 'that 'critique' is never more interesting, never more convincing, never more far-sighted, than when it tends and even drifts towards 'clinique"' (Damisch 2000: 94). But where they have asserted psychoanalysis's masteryits capacity to theorize literature on its own terms-psychoanalytic literary critics have necessarily overlooked or disavowed this disfiguration of the object that constitutes their practice. In short, when it conceives of its relation as vertical, psychoanalysis cannot help but assume that it understands (and stands under) any object. Psychoanalysis must assume that its conceptual repertoire is commensurate with any given text, simply because psychoanalytic meaning is always assumed to be more fundamental, and to lie beneath art's formal and technical qualities, awaiting excavation. If we see the relation as horizontal, however, psychoanalysis provides a method of challenging and provoking its objects-by admitting a certain amount of necessary error or misrecognition, certainly, but not by assuming it already has the answers. In this way, the criterion for productive encounters between literature and psychoanalysis becomes not the "discovery" or approximation of psychoanalytic axioms or concepts in texts but the mutual disruption of both literary critical and psychoanalytic norms.

\section{Romanticism contra psychoanalysis}

The remainder of this essay aims to flesh out an alternative, non-reciprocal conception of psychoanalytic literary criticism by way of two brief examples, both from British romantic poets. I set Wordsworth and Shelley against Freud, though my selection of poets and psychoanalyst here is wholly contingent. These are intended to be illustrative rather than comprehensive, and for this reason the discussion will be rather narrow, focusing on a pair of interpretive problems in which literary critical and psychoanalytic questions impinge on one another. 
My first example is drawn from Wordsworth's “Lines written a few miles above Tintern Abbey, on revisiting the banks of the Wye during a tour." On the occasion of revisiting the Wye, the poet reflects on the pleasure he had felt following his previous visit:

Though absent long,

These forms of beauty have not been to me,

As is a landscape to a blind man's eye:

But oft, in lonely rooms, and mid the din

Of towns and cities, I have owed to them,

In hours of weariness, sensations sweet

(Wordsworth 1992 [1798]: 117)

There is a common interpretation of these lines: that they demonstrate Wordsworth's expansion of memory, which becomes capable not only of recollection, but of recovering aesthetic and spiritual value from past experience. A number of accounts connect the poem to John Locke's account of memory, and suggest a resonance with Locke's image of memory as a storehouse (Sperry, Ferguson, Fairer). Indeed, the poet's own metaphors of memory as a "dwelling-place" and the mind "a mansion for all lovely forms" seem to prompt a Lockean reading of the poem (1992: 120). Yet there is also a case to be made that much of the value of past experience in the poem lies outside of memory. Without having space here to engage individually with the sophisticated accounts I have cited, I want to suggest the conditions in which psychoanalysis might generate a helpful response to a broadly Lockean reading of the poem. For this purpose, I take the essential claim to be that Wordsworth's efforts to revisit past scenes through writing can be understood as a conscious and intentional labor of memory (where "Personality extends it self beyond present Existence to what is past, only by consciousness[.]") (Locke 1979 [1689]: 346) "Tintern Abbey" would then be, in Charles S. Maier's attractive formulation, "the fugal contemplation of Wordsworth's remembering self' (1993: 139). 
For those interested in the conjunction of literature and psychoanalysis, one objection to this line of argument will be clear: it leaves no space for unconscious experience. Any approach which understands the value of the past for Wordsworth to subsist wholly in what can be consciously perceived and recollected will be unable to consider the portions of experience which elude memory or escape notice. This objection is immediately useful in questioning the explanatory power of a Lockean reading of the poem. Once we are alerted to the potential for gaps and distortions in memory, certain details in the poem become more obviously important. Firstly, it is clear that in "Tintern Abbey" the significance of particular experiences changes over time. The restorative power of the rural scenes felt "in lonely rooms" comes in part from the change of context: as water tastes delicious after extreme thirst, so are the "forms of beauty" sweetened by the "hours of weariness" that followed and transformed them. To return to these scenes now is not to visit a closed "storehouse" or archive but to find new meaning in past experience. More strikingly, the poet's relief and balm comes from past sensations on the very border of the rememberable, and sensations altogether beyond it: "gleams of half-extinguish'd thought, / With many recognitions dim and faint," and "feelings too / Of unremembered pleasure," feelings which themselves shape those "little, nameless, unremembered acts / Of kindness and of love." In short, Wordsworth's reflections on the previous visit to the Wye valley are as much a confrontation with the limits and failures of memory as they are a work of recollection. Portions of past experience now appear as blank spots: "I cannot paint / What then I was" (1992: 117-8). If one accepts the possibility of unconscious and unremembered experience, at least, the poem's considerable investment in the healing capacity of past events can be understood not as a work of memory but an attempt to reach beyond memory, and in doing so show that any given moment might one day come to mean more than we can presently know.

By stating the objection in this way, however, we have done no more than suggest commonality between Wordsworth's poetry and psychoanalytic attitudes. This risks affording psychoanalysis the explanatory priority, not only distracting from Wordsworth's own attention to 
memory and its limits, but implicitly setting the stakes of the interpretation as essentially a battle between Locke and Freud, in which the poem is territory that one or the other might capture. Psychoanalysis and literature are more likely to be relevant when there is some topic or concept at stake in which they are both invested, but we need to consider commonality of interest while allowing for divergent and incompatible consequences. And in order to put poetry and psychoanalysis in a horizontal relation, both need to be presented as particulars. To draw a specific comparison, we might consider the poem in light of some remarks from Freud's "Introductory Lectures on Psycho-Analysis," given in 1915 and 1916. At the beginning of lecture thirteen, Freud speaks of

the remarkable amnesia of childhood. I mean the fact that the earliest years of life, up to the age of five, six or eight, have not left behind them traces in our memory like later experiences. Here and there, it is true, we come upon people who can boast of a continuous memory from the first beginnings to the present day; but the other alternative, of gaps in the memory, is by far the more frequent. (Freud 2001c [1916]: 199200)

It is part of Freud's rhetorical strategy in these lectures to introduce his theoretical commitments tentatively (he is yet to introduce the term "repression.") As a consequence, he limits himself here to sketching a contrast between childhood and what adults remember of it:

Our memory ... retains what is of any importance and drops what is unimportant. But this is not true of the childhood memories ... They are often so commonplace and insignificant that we can only ask ourselves in astonishment why this particular detail has escaped oblivion. (2001c: 199-200) 
Just by laying out the problem like this, Freud suggests that beyond remembered childhood there is another, more significant version of childhood, in which those portions which now seem "dim and faint" or "unremembered" might be the most important of all. Freud's story of childhood is one of repression and amnesia, in which the most consequential scenes are covered over or lost to consciousness. Yet in his handling of these unremembered scenes Freud will diverge sharply from Wordsworth. Psychoanalysis aims to "lift the veil of amnesia which hides the earliest years of childhood," Freud says in a later lecture, in order to reveal "painful impressions of anxiety, prohibition, disappointment and punishment" (2001e [1933]:28). For Freud, early experiences go missing because they are painful; the mind preserves itself by disowning things it cannot tolerate. Children's desires, and particularly their desires for monopolistic love, go unmet but not unpunished, and so with the inevitable disciplining of desire comes the unavoidable amnesia. As John Forrester has observed, “[p]sychoanalysts ... seek out the bad experiences of a person's remembered childhood ... if you are seeking out bad infantile experiences because you have at the back of your mind an ideal of an innocent childhood, which can be restored, you are moving in the opposite direction from psychoanalysis" (1997: 240).

This divergence explains why "vertical" psychoanalytic accounts of Wordsworth invariably tend towards diagnoses of trauma; for psychoanalysis, repressed material must be painful material, and thus a "vertical" psychoanalytic reading of "Tintern Abbey" would know that the elisions and gaps in Wordsworth's account signify traumatic episodes. Consequently, that reading would be duty-bound to overlook the poet's

\section{feelings too}

Of unremembered pleasure; such, perhaps,

As may have had no trivial influence

On that best portion of a good man's life;

His little, nameless, unremembered acts 
Of kindness and of love.

(1992: 117)

Despite being a clear and, I think, rather attractive proposition, the value of "little, nameless, unremembered acts" has been downplayed by recent critics. Thomas Pfau asks "what meaning, after all, can we possibly assign to 'unremembered pleasure'?” (1997: 134-5). And Laura Quinney contends that by suggesting "their failure to be so much as 'remembered," Wordsworth makes "a major concession to pessimism" (1997: 143). One explanation for the critical dereliction of unremembered pleasure in Wordsworth is that it is ostracized twice over, ostracized by commonsense British empiricism and ostracized again by psychoanalysis, for which this is an affront to its metapsychology. Lost infant joy, a theme which Wordsworth never gives up, is shown to be significant by posing psychoanalytic questions, but remains unavailable for as long as we imagine that psychoanalysis explains Wordsworth.

Read alongside Freud's account of infantile amnesia, "Tintern Abbey" begins to look strikingly different. Merely by asking where unconscious and unnoticed experience belong in Wordsworth's poem, it becomes possible to understand the discontinuities between past and present not as mistakes but discoveries. It becomes possible to ask whether the act of writing about past experience-like the process of talking about it—might not be an opportunity to discover that the past included more than you thought: not because writing misrepresents "what really happened," but because the act of retrospection might itself reveal something previously unfelt. The persistence and discontinuity of "our childhood" is a crucial subject for both Wordsworth and Freud. But by setting Wordsworth's attention to unconsciousness against psychoanalysis, we can begin to see a different approach, which ventures to trace the role of positive affects that were once abundant and yet resistant to memory. The youth recalled in "Tintern Abbey," who "like a roe," "bounded o'er the mountains" might have recorded no tranquility in nature not because none was there, but because he was so thoroughly a part of that 
natural scene that its deep harmony was merely the background against which each breathless afternoon unfolded (1992: 118). Thus the mature figure can return to those scenes feeling for the first time the calm in which once he bathed, a calm which becomes tangible only after it has broken, just as silence becomes almost audible when a loud noise ceases. On this account, the poet at work does not alter the past but, by returning to it, consciously experiences elements of it for the first time.

There is no need to speculate about what the biographical Wordsworth might have known and forgotten in order to read a poem that ventures to think through memory and forgetfulness. But by insisting that the poem addresses what cannot be remembered, it becomes possible to approach “Tintern Abbey," and ultimately Wordsworth's broader project, not as the poetry of memory but as an attempt to confront in writing the discontinuities of the past, and to find in lost and unremembered experience grounds for tranquility and joy. Psychoanalytic theory might shape interpretation of the poem without supposing to explain it. Indeed, the point at which incompatibility arises is the point at which Wordsworth's particularity begins to emerge. By reading Wordsworth against Freud it becomes possible to plot another, competing narrative, a history and science of unremembered pleasure, as it were; and by setting Freud against Wordsworth we can ask in turn why it is that psychoanalysis proves so resistant to the notion of affective plenitude - to what Wordsworth calls bliss. ${ }^{10}$

My second example focuses on a remark of Percy Shelley's. In a prose fragment composed around 1818 and published by Mary Shelley in The Keepsake annual (1829) as "On Love," Shelley remarks that "there is something within us which from the instant that we live and move thirsts after its likeness" (2002 [?1818]: 504). This has been interpreted as an affirmation of what Freud calls narcissistic object-choice. Indeed, it is something of a critical commonplace to observe Shelley's narcissism. ${ }^{11}$ As in the case of Wordsworth and the term

\footnotetext{
${ }^{10}$ I investigate the implications of this "Wordsworthian unconscious" in Freer 2015 and in a larger ongoing project. 11 The observation goes back to at least Read (1953: 257-9). Important examples since include Mellor (1988: 8) and Frosch (2007: 70-6).
} 
repression, there is a tendency in the critical literature to use narcissism in a semi-technical way, meaning both attachment based on likeness, and as a simple character defect. Thus a loosely psychoanalytic concept of narcissism can sometimes be invoked both to characterize Shelley's writing and theorization of love and to "explain" the women depicted in Shelley's work and Shelley's treatment of empirical women.

Here too I am concerned with the potential friction between a literary and a psychoanalytic approach to a related group of concepts. There is much to be gained by reading Shelley's remark about love's thirst for likeness alongside a more strictly psychoanalytic conception of narcissism, even at the risk of taking Shelley's fragment rather more seriously than a contemporary reader might have. Freud inherits from Paul Näcke the term "Narcismus" to describe a sexual perversion. But by turning in his seminal 1915 paper "On Narcissism" to "the conception of a primary and normal narcissism," Freud turns a pathology into an element of general psychology (Freud 2001b [1914]: 73-4). Although the popular legacy of Freud has reversed this to some degree, Freud does not think of the world divided into narcissists and other people, but understands narcissism as one possible structuring logic of desire, and thus as an aspect of every person's motivated activity, which can be either less pronounced or more pronounced, and can be to a pathological degree. This stance allows us to separate narcissism as psychological concept from narcissism as a personal trait or flaw. Rather than asking if Shelley is a narcissist (that is, does the psychoanalytic concept "explain" the historical Shelley and/or his writing?), we can pose a more substantial comparative question: what intellectual work does narcissism do for Shelley and for Freud?

One function of narcissism for Freud is to order and connect other psychological concepts. This can be seen clearly in his return to the topic of melancholia in 1917, where narcissism provides a solution to the previously unresolved question of why some forms of bereavement lead to mourning and others melancholia. Freud uses narcissism to articulate the damage some bereavements can cause not only to a person's love for the deceased but also their 
capacity to love themselves. This is pertinent not because Shelley thinks, or his work exemplifies, any of these ideas, but because for Shelley too, love through likeness becomes an organizing principle. Shelley uses his own "law" of attraction to likeness to work through and explain morality, aesthetics and the history of art in the Defence of Poetry. The love of likeness has, for Shelley, the grandeur that the concept of recognition has for Hegel, and by reading Shelley's accounts with Freud's, it becomes possible to draw out the significant roles narcissism plays for each. But in this case too, it is necessary to read Shelley against Freud in order to gain purchase on both. Shelley defines love like so:

It is that powerful attraction towards all we conceive or fear or hope beyond ourselves when we find within our own thoughts the chasm of an insufficient void and seek to awaken in all things that are a community with what we experience within ourselves (2002: 503).

On Shelley's account we love our likeness in others because we are insufficient by ourselves. This is partly an articulation of his sympathy for the view held by Aristophanes in Plato's Symposium, which Shelley translated in July 1818, very likely just before he composed "On Love." For Aristophanes, we go looking for the lost part of ourselves which is now another person. But this also means that Shelley's narcissism is always at the same time a furious attempt to make oneself lovable, whereas for Freud narcissistic love of the self provides the model for a certain "type" of relation to others.

Another way to state this opposition is that for Freud, love is a private good, while for Shelley it is necessarily social. In Freud's famous rebuke to the injunction to love one's neighbor, he objects: "[m]y love is something valuable to me which I ought not to throw away without reflection" (2001d: 109). If love is scarce and private, narcissistic object-choices can be understood as a kind of self-preservation; they provide "substitutive satisfaction," allowing a 
person to "love what he once was and no longer is, or else what possesses the excellences which he never had at all" (2001b: 101). For Shelley, love is rather "the bond and the sanction which connects not only man with man, but with every thing which exists." (2002: 504) It is not that some love is self-centered or premised on reflexivity for Shelley; rather, love simply is, in David Bromwich's words, "[a] power of the mind founded on nothing but human recognition" (2002: 256). If for Freud narcissistic love-objects preserve self-love, for Shelley likeness is what allows love to emerge as love, not hunger.

By approaching Shelley's narcissism in conjunction with Freud's writing on the topic, it becomes possible to see narcissism's structuring role in Shelley's writing while resisting the critical impulse to frame it in terms of his biography, and resisting the widely-held assumption in psychoanalytic readings of Shelley that we know, and agree on, what narcissism is. Moreover, reading Freud's theory against Shelley's prose suggests that for both, an account of love is always implicitly a kind of social theory, but that these two theories are divergent in the extreme. In order to take Shelley's narcissism seriously, psychoanalysis needs to be kept visible precisely so that we appreciate what is distinctive about Shelley's approach. Equally in order to understand psychoanalysis productively, as a contingent history of theories and debates, rather than a fixed set of beliefs, a foil like romanticism is required to show how key concepts can be thought and used differently.

In this case, by setting Freud against Shelley, Freud's 1917 account of narcissism appears more clearly marked by his reliance on the economic theory of the libido and by his inclination towards social atomism, underscoring the importance of making space for other potential psychoanalytic accounts of narcissism, centered not on the internal libidinal economy of a selfmaximizing individual but on the capacity to enjoy interpersonal relations and even to form "impersonal" relations (see Bersani and Phillips 2008: 89-117). Further, the comparison foregrounds certain stylistic qualities in Shelley's "On Love." Shelley's uses of address proceed from the "I" and "thou" that enforce separation to the inclusive "we" which asserts 
correspondence - the correspondence between poet and audience that Shelley's argument ultimately depends on-and gives the fragment a quality approaching lyric. The difficult opening lines, which critics wanting to quote Shelley's "position” on love generally overlook, suggest a situation of social breakdown. "I know not the internal constitution of other men, or even thine whom I now address," Shelley declares. This address is at once a claim on his reader (I am now speaking to you) and a repudiation of that claim (but what is true of me may not be of you). The fragment denies knowledge of others at the outset, yet before the end asserts a correspondence between lovers, between infants and mothers, between lonely people and "the flowers, the grass and the waters and the sky" (and implicitly between writer and reader, between writer and "other men"). In this way the fragment arcs towards likeness, and thus "On Love" performs its own drama of love, moving from solitude to sympathy (and lastly to death, a transition which would also reward comparison to Freud) (Shelley 2002: 503-4). If we are to speak productively of Shelley's narcissism, the term will need to encompass its lyrical and theoretical qualities, and its self-reflexive nature as well as the way psychoanalysis has accustomed literary critics to think of narcissism: as a limiting factor in, or even a failure of, sociality.

Both examples illustrate positions from which criticism that sets poetics against psychoanalysis might begin. Both risk a certain distortion of their subjects, but they never suppose poetics and psychoanalysis to explain or encompass one another. Since this method assumes that each instead alters and modifies the other, this approach necessarily requires the study of particulars — a Freudian Wordsworth will differ from a Kleinian Wordsworth, and Shelley's Freud from Charlotte Smith's Freud. But it is hoped that these brief sketches signal the potential for psychoanalytic literary criticism to disturb both literary critical reflexes and psychoanalytic axioms by reading poetics against psychoanalysis.

\section{Coda}


Psychoanalysis is obsessed with making theories, yet also committed to diagnosing-and undermining-people's obsessive attempts to theorize. It is no surprise that it has always been trying to incorporate literature into that dialectic of theory and its subversion. Equally, literary criticism has ample resources to suppress the aspirations of any text to the function of theory, from formal and rhetorical analysis to historical and generic contextualization, even down to aesthetic or personal responses (would Freud have wavered for a second between being thought a great writer and being recognized to have seized on the difficult truth?) But by accepting the friction between poetry and psychoanalysis, it becomes possible to see that friction as a source of heat and light by which an investigation can proceed.

Reconsidering literary criticism and psychoanalysis in this way allows us to rethink the motives for psychoanalytic literary reading. For the Freud of "Creative Writers and DayDreaming," the desires of the text are the desires of an author, obfuscated to a lesser or greater degree. The payoff for all readers consists in getting through the aesthetic obfuscation, back to the author's fantasy. Thus the psychoanalytic reader who seeks out the author by analyzing or decoding the text is, in this model, doing the same as every other reader, only with sharper tools. The object of desire is not the writing itself, but the psyche which, it is assumed, gets caught up in its production, and remains beyond, behind or beneath it. Hélène Cixous writes: "I want the beforehand of a book ... I want the forest before the book, the abundance of leaves before the pages, I love the creation as much as the created, no, more" (1993: 91). Psychoanalysis thirsts for the moment at which writing and desiring intersect. But by misconstruing this thirst as criticism, the prototypical psychoanalytic literary critic is always looking for a way to stop reading and get back to psychoanalysis.

Once we abandon the notion that psychoanalysis and literature explain one another, it becomes possible to identify a second desire, based not on similarity or understanding but on difference and disruption. In a characteristic one-liner, Phillips declares: "psychoanalysis is about what two people can say to each other if they agree not to have sex" (2002: xx). By the same 
token, what can we say about literature if we agree not to have analysis? In the absence of any hoped-for consummation of poetics and psychoanalysis, what we need to grasp is not how the literary shapes and produces psychoanalytic writing (the influence of Wilhelm Jensen on Freud, or the stylistics of Klein), nor how psychoanalysis interprets the writing process (i.e., literary psychobiography), but what happens when the demands and strictures of literary writing rub up against those of psychoanalysis; when both risk their potential disfigurement before the other. This too can be a motivating force; Barthes writes: "I would go so far as to take bliss in a disfiguration of the language" (1975: 37). To read literature against psychoanalysis is to forsake the pleasure of recognition — which is ultimately a matter of confirming what we already know-but seize the chance to be caught out by the way in which each resists and exceeds the other, and in doing so resituate our thinking about both.

\section{References}

Barthes, Roland

1975 The Pleasure of the Text trans. Richard Miller. (New York, NY: Farrar. Straus and Giroux). 1990 [1970] S/Z trans. Richard Miller (Oxford: Blackwell)

Bersani, Leo.

1986 The Freudian Body: Psychoanalysis and Art (New York: Columbia UP).

2010 "Broken Connections," PMLA 125.2: 414-417.

Bersani, Leo and Adam Phillips.

2008 Intimacies (Chicago: Chicago UP).

Bowie, Malcolm.

1987 Freud, Proust and Lacan: Theory as Fiction (Cambridge: Cambridge UP).

Bromwich, David.

2002 "Love Against Revenge in Shelley's Prometheus" Philosophy and Literature 26: 239-259.

Brooks, Peter.

1987 “The Idea of a Psychoanalytic Literary Criticism,” Critical Inquiry 13.2: 334-348. 

Alex Woloch, 15-19 (New Haven: Yale UP).

Chamberlain, Lesley.

2000 The Secret Artist: A Close Reading of Sigmund Freud (London: Quartet)

Civitarese, Giuseppe and Antonino Ferro

2013 “The Meaning and Use of Metaphor in Analytic Field Theory," Psychoanalytic Inquiry 33.3: 190-209.

Cixous, Hélène

1993 "Without End no State of Drawingness no, rather: The Executioner's Taking off," trans. Catherine MacGillivray. New Literary History 24.1: 91-103.

Cohen, Tom.

1995 “Beyond 'The Gaze’: Žižek, Hitchcock, and the American Sublime,” American Literary History 7.2: 350-378.

Culler, Jonathan.

2015 Theory of the Lyric (Cambridge, MA: Harvard UP)

Damisch, Hubert

2000 "Bridging the Gap Between Two Scenes" in Brooks 2000: 93-95.

Dean, Tim.

2002 “Art as Symptom Žižek and the Ethics of Psychoanalytic Criticism” Diacritics 32.2: 21-41.

Egginton, William.

2007 The Philosopher's Desire: Psychoanalysis, Interpretation, and Truth (Stanford: Stanford UP)

Enckell, Henrik

1999 "Transference, metaphor and the poetics of psychoanalysis," The Scandinavian Psychoanalytic Review 22 (2): 218-238.

Faflak, Joel

2007 Romantic Psychoanalysis: The Burden of the Mystery (New York: SUNY Press)

David Fairer

2013 “Revisiting 'Tintern Abbey': The Challenge of the Familiar” Romanticism 19/2: 179-187.

Felman, Shoshana

1977 a “Turning the Screw of Interpretation," Yale French Studies 55/56: 94-207.

1977b “To Open the Question,” Yale French Studies, 55/56: 5-10.

Felski, Rita.

2011 “Suspicious Minds,” Poetics Today 32: 215-234. 
Ferguson, Frances

2005 "Romantic Memory" in The Wordsworthian Enlightenment: Romantic Poetry and the Ecology of Reading eds. Helen Regueiro Elam and Frances Ferguson, 71-96 (Baltimore: The Johns Hopkins UP).

Forrester, John

2015 “Adam Phillips and the Making of a Psychoanalyst” Psychoanalysis and History 17.1: 107-119.

1997 Dispatches from the Freud Wars: Psychoanalysis and Its Passions (Cambridge, MA: Harvard UP).

Freer, Alexander

2015 "Wordsworth and the Infancy of Affection" Studies in Romanticism 54: 79-99.

Freud, Sigmund

2001a [1908] "Creative Writers and Day-Dreaming" in The Standard Edition of the Complete Psychological Works of Sigmund Freud Volume IX, 141-154 (London: Vintage).

2001b [1914] "On Narcissism" in The Standard Edition of the Complete Psychological Works of Sigmund Frend Volume XIV, 67-102 (London: Vintage).

2001c [1917] "Introductory Lectures on Psycho-Analysis" Parts I and II in The Standard Edition of the Complete Psychological Works of Sigmund Frend Volume XV, 1-240 (London: Vintage).

2001d [1930] "Civilization and its Discontents" in The Standard Edition of the Complete Psychological Works of Sigmund Frend Volume XXI, 57-146 (London: Vintage).

2001e [1933] "New Introductory Lectures On Psycho-Analysis" in The Standard Edition of the Complete Psychological Works of Sigmund Freud, Volume XXII, 1-182 (London: Vintage).

Frosch, Thomas R.

2007 Shelley and the Romantic Imagination: A Psychological Study (Newark: University of Delaware Press).

Gallop, Jane

1984 "Lacan and literature: a case for transference," Poetics 13: 301-308.

1979 “The Seduction of an Analogy," Diacritics 9.1: 45-51.

2010 “Bersani’s Freudian Body,” PMLA 125.2: 393-397.

Green, André.

1997 [1986] On Private Madness. (London: Karnac Books)

Grimaud, Michel

1984 "Poetics from Psychoanalysis to Cognitive Psychology" Poetics 13: 325-345.

Groeben, Norbert

1984 "Meta-theoretical problems of psychoanalytical interpretation of literature," Poetics 13: 407-420. 
Gudas, Fabian and Michael Davidson

1993 "Voice" in The New Princeton Encyclopedia of Poetry and Poetics ed Alex Preminger and T. V. F. Brogan, 13661367 (Princeton: Princeton UP)

Gunn, Joshua.

2004a “On Dead Subjects: A Rejoinder to Lundberg on (a) Psychoanalytic Rhetoric," Quarterly Journal of Speech 90.4: 501-513.

2004b "Refitting Fantasy: Psychoanalysis, Subjectivity, and Talking to the Dead" Quarterly Journal of Speech 90.1: 123.

Hillman, David

2012 "Part II: Freud" in Marx and Frend (Great Shakespeareans) eds. Peter Holland and Adrian Poole, 99-176 (London: Bloomsbury)

Ingram, Douglas

1996 "How words mean in analytic psychotherapy" The Journal of the American Academy of Psychoanalysis and Dynamic Psychiatry 24: 527-541.

Jacobus, Mary.

1998 “The Pain in the Patient's Knee” Diacritics 28.4: 99-110

2005 The Poetics of Psychoanalysis in the Wake of Klein (Oxford: Oxford UP).

Jameson, Fredric

1971 “Metacommentary” PMLA 86/1: 9-18.

Johnson, Barbara

1977 "The Frame of Reference: Poe, Lacan, Derrida" Yale French Studies 55/56: 457-505.

Kristeva, Julia

1980 Desire in Language: A Semiotic Approach to Literature and Art. Trans. Thomas Gora (New York: Columbia UP). Lacan, Jacques

2006 [1966] Écrits: The First Complete Edition in English Trans. Bruce Fink (New York: WW Norton).

2013 [1971] "Lituraterre” trans. Dany Nobus. Continental Philosophy Review 46: 327-334.

2009 [1971] "Lituraterre [transcription]," Patrick Valas: Médecin, Psychiatre, Psychanalyste, http://www.valas.fr/IMG/pdf/Lacan_Lituraterre12051971.pdf (accessed October 26, 2016)

Locke, John.

1979 [1689] An Essay Concerning Human Understanding. ed. P.H. Nidditch. (Oxford: Clarendon P, 1979).

Lundberg, Christian 
Maier, Charles S.

1993 “A Surfeit of Memory? Reflections on History, Melancholy and Denial” History and Memory 5/2: 136-152.

Mellor, Anne K.

1988 "On Romanticism and Feminism" in Romanticism and Feminism ed. Anne K Mellor, 3-9 (Bloomington: Indiana UP).

Nobus, Dany

2003 "Lacan's science of the subject: between linguistics and topology" in The Cambridge Companion to Lacan Ed. Jean-Michel Rabaté, 50-68 (Cambridge: Cambridge UP).

2013 "Annotations to Lituraterre" Continental Pbilosophy Review 46: 335-347.

Nowell Smith, David

2015 On Voice in Poetry: The Work of Animation (Basingstoke: Palgrave MacMillan.

Ogden, Benjamin H. and Ogden, Thomas H.

2013 “What Is Psychoanalytic Literary Criticism?” fort da 19.1: 8-28.

Ogden, Thomas H

1998 “A Question of Voice in Poetry and Psychoanalysis" Psychoanalytic Quarterly 67, 426-448.

Patterson, Ian.

2002 "Bad Dreams and Secret Artists: Translating Freud into Literature," Psychoanalysis and History 4.2: 127-139.

Pfau, Thomas.

1997 Wordsworth's Profession: Form, Class, and the Logic of Early Romantic Cultural Production (Stanford: Stanford UP)

Phillips, Adam.

1995 On Flirtation (London: Faber and Faber).

1997 Terrors and Experts (London: Faber and Faber).

2000 Promises, Promises (London: Faber and Faber).

2002 "Introduction" in Wild Analysis by Sigmund Freud. Trans. Alan Bance, vii-xxv (London: Penguin).

2003 “Making the Case: Freud's Literary Engagements” Profession: 10-20.

2014 Becoming Freud: The Making of a Psychoanalyst (New Haven, CT: Yale UP)

Quinney, Laura.

1997 “'Tintern Abbey,' Sensibility, and the Self-Disenchanted Self” ELH 64/1: 131-156.

Rabaté, Jean-Michel

2001 Jacques Lacan: Psychoanalysis and the Subject of Literature. (Basingstoke: Palgrave MacMillan) 

Seagull).

Read, Herbert.

1953 The True Voice of Feeling: Studies in English Romantic Poetry (London: Faber).

Richards, Eliza

2012 "Voice" in The Princeton Encyclopedia of Poetry and Poetics Fourth Ed, ed Roland Greene et al., 1525-1527 (Princeton: Princeton UP).

Schlicke, Paul (ed.)

2011 The Oxford Companion to Charles Dickens (Oxford: Oxford UP).

Sedgwick, Eve Kosofsky

2003 Touching Feeling: Affect, Pedagogy, Performance (Durham, NC: Duke UP).

Shelley, Percy Bysshe

2002 Shelley's Poetry and Prose Eds. Donald H. Reiman and Neil Fraistat (New York: Norton).

Sperry, Stuart M

1970 "From 'Tintern Abbey' to the 'Intimations Ode': Wordsworth and the Function of Memory," The Wordsworth Circle 1: 40-49

Szajnberg, N.M.

1997 "The Aesthetic Aspects of Psychoanalysis" The Journal of the American Academy of Psychoanalysis and Dynamic Psychiatry 25: 189-210.

Wordsworth, William

1992 [1798] Lyrical Ballads, and Other Poems, 1797-1800. eds James Butler and Karen Green (Ithaca: Cornell UP). Young, Robert

1999 "Freud's Secret: The Interpretation of Dreams was a Gothic Novel" in Sigmund Freud's The Interpretation of Dreams: New Interdisciplinary Essays Ed. Laura Marcus, 206-231 (Manchester: Manchester UP).

Žižek, Slavoj

1998 (ed.) Cogito and the Unconscious. (Durham, NC: Duke UP).

1994 The Metastases of Enjoyment. (London: Verso). 